\title{
PENGGUNAAN POWER POINT DAN LEAFLEAT TERHADAP PENINGKATAN PENGETAHUAN SISWA KELAS IX TENTANG P3K DI SMP TUNAS KARYA BATANG KUIS TAHUN 2017
}

\author{
The Effect of Use of Power Point and Leafleat on Knowledge of Class IX Students About \\ First Aid In Accident (First Aid) at Junior High School Tunas Karya Batang Kuis 2017 \\ Resmi Pangaribuan ${ }^{1}$ dan Muchti Yuda Pratama ${ }^{2}$ \\ ${ }^{1,2}$ Dosen Tetap Yayasan Wahana Bhakti Karya Husada Akper Kesdam I/BB Medan \\ mail: resmi.pangaribuan@yahoo.co.id, yudamuchi@yahoo.co.id
}

\begin{abstract}
Abstrak
Kondisi kegawatdaruratan dapat terjadi dimana saja, kapan saja dan sudah menjadi tugas dari petugas kesehatan untuk menangani masalah tersebut. Kematian terjadi biasanya karena ketidakmampuan petugas kesehatan untuk menangani penderita pada fase gawat darurat (golden period). Usaha ini harus dimulai dengan mengenali secara tepat keadaan pasien kecelakaan.

Penelitian ini bertujuan untuk mengetahui pengaruh penggunaan power point dan Leafleat terhadap pengetahuan siswa kelas IX di SMP Tunas Karya Batang Kuis. Jenis penelitian ini adalah Quasi eksperimen two group pretest-posttest. Total populasi dalam penelitian ini adalah siswa kelas SMP Kelas IX Pertolongan pertama pada kecelakaan (Firs Aid) sebanyak 110 orang. Hasil penelitian yang dilakukan secara statistik menunjukkan media power point dan leafleat mempengaruhi peningkatan pengetahuan siswa kelas IX tentang Pertolongan pertama pada kecelakaan (P3K). Disarankan kepada siswa/siswi untuk meningkatkan pengetahuan tentang Pertolongan pertama pada kecelakaan (Firs Aid) dalam menolong korban yang memerlukan pertolongan kegawatdaruratan dengan segera dan siap pakai dalam situasi urgent. Kepada pimpinan Yayasan untuk mengambil kebijaksanaan dalam pendidikan kesehatan, untuk lebih meningkatkan pengetahuan siswa/siswi untuk mengadakan pelatihan Pertolongan pertama pada kecelakaan (Firs Aid) dan membentuk Palang Merah Remaja.
\end{abstract}

Kata Kunci : Media power point, Leafleat, Pengetahuan, Pertolongan pertama pada kecelakaan (P3K)

\begin{abstract}
\section{PENDAHULUAN}

Pertolongan Pertama Pada

Kecelakaan (P3K) merupakan pertolongan pertama yang harus segera diberikan kepada korban yang mendapatkan kecelakaan atau penyakit mendadak dengan cepat dan tepat sebelum korban dibawa ke tempat rujukan atau Rumah sakit. Kondisi kegawatdaruratan dapat terjadi dimana saja, kapan saja dan sudah menjadi tugas dari petugas kesehatan
\end{abstract}

Emergency conditions can occur anywhere, anytime and it is the duty of health workers to handle the problem. Death occurs usually because of the inability of health workers to deal with patients in the golden period. This effort must begin by correctly identifying the condition of the accident patient.

This study aims to determine the effect of using power point and Leafleat on the knowledge of class IX students at SMP Tunas Karya Batang Kuis. The type of this research is Quasi experiment two group pretest-posttest. The total population in this study was first class IX First Class Middle School students in accidents (Firs Aid) of 110 people. The results of the research carried out statistically showed that power point and leafleat media influenced the increase in knowledge of class IX students on first aid (P3K). It is recommended for students to increase knowledge about first aid in accidents (Firs Aid) in helping victims who need emergency assistance immediately and are ready to use in urgent situations. To the leadership of the Foundation to take wisdom in health education, to increase the knowledge of students to hold first aid training on accidents (Firs Aid) and form the Youth Red Cross.

Keywords: To use power point, Leafleat, Knowledge, First aid in accident

untuk menangani masalah tersebut. P3k yang dimaksud yaitu memberikan siswa kelas IXan darurat pada korban, sebelum pertolongan pertama yang lengkap diberikan oleh dokter atau petugas kesehatan lainnya. P3k diberikan untuk menyelamatkan korban, meringankan penderitaan korban, mencegah cidera atau penyakit yang lebih parah, 
mempertahankan daya tahan korban, dan mencarikan pertolongan yang lebih lanjut.

Ada pun prinsip-prinsip pertolongan terhadap korban serta beberapa peralatan yang diperlukan terhadap korban namun tidak semua ada, akan tetapi kita dituntut kreatif dan mampu menguasai setiap keadaan. Kematian terjadi biasanya karena ketidakmampuan petugas kesehatan untuk menangani penderita pada fase gawat darurat (golden period). Berdasarkan hasil observasi dan wawancara yang dilakukan oleh peneliti pada Masyarakat di SMP Tunas Karya Batang kuis tentang pertolongan pertama pada kecelakaan (First Aid) pada korban, didapatkan hasil bahwa kemampuan memahami dan melakukan pertolongan pertama pada kecelakaan (First Aid) pada korban masih minim dan angka keberhasilan melakukan tindakan pertolongan pertama pada kecelakaan (First Aid) pada korban masih sedikit. Masyarakat pernah mendengar tentang tindakan ini tetapi dengan kurangnya pengetahuan masyarakat tentang pertolongan pertama pada kecelakaan (First Aid) ini pertolongan yang diberikan kepada korban belum efisien. Dimana dari kasus tersebut diatas diperlukan kemampuan seseorang untuk melakukan tindakan pertolongan pertama pada kecelakaan (First Aid) sebagai orang pertama yang menyaksikan/menemukan korban kecelakaan. Hal ini merupakan dasar untuk menyelamatkan nyawa pasien.

\section{METODE}

\section{Jenis Penelitian}

Jenis penelitian yang digunakan adalah eksperimen semu (quasi experiment) dengan rancangan pretest-posttest design with two group. Rancangan penelitian sebelum dan sesudah intervensi dengan menggunakan kelompok pembanding

\begin{tabular}{|ccc|}
\hline PRE TEST & POST TEST \\
O1 & $\mathrm{X}$ & $\mathrm{O} 2$ \\
$\mathrm{O} 3$ & $\mathrm{X}$ & $\mathrm{O} 4$ \\
\hline
\end{tabular}

Gambar 3.1. Rancangan Pretest-Posttest Design
Penelitian ini dilakukan mulai dari Oktober Tahun SMP Tunas Karya Batang Kuis

Populasi dalam penelitian ini adalah kelas IX A dan kelas IX B SMP Tunas Karya Batang kuis. Adapun populasi dalam penelitian ini berjumlah 110 orang siswa/siswi SMP Tunas Karya.

Adapun sampel dalam penelitian ini adalah berjumlah 110 orang dan dibagi menjadi dua kelompok terdiri dari

1. Kelompok 1 terdiri dari 55 orang siswa/siswi yang akan diberikan penyuluhan kesehatan dengan power poin

2. Kelompok 2 terdiri dari 55 orang siswa/siswi diberikan penyuluhan kesehatan dengan Leafleat.

\section{Metode Pengumpulan Data}

Metode pengumpulan data dalam penelitian ini adalah menggunakan kuesioner yang dikembangkan berdasarkan teori tentang pertolongan pertama pada kecelakaan (First Aid) susuai dengan penelitian yang sudah baku. Cara pengukuran dilakukan dengan menggunakan kuesioner yang sudah baku.

\section{HASIL \\ Gambaran SMP Tunas Karya Batang Kuis}

SMP Tunas Karya Batang Kuis beralamat di jalan Batang Kuis, bakaran batang kuis kabupaten Deli serdang Sumatera Utara, kode pos. 20372. Kepala sekolah SMP Tunas Karya dipimpin oleh Sri Hastuti, SH. SMP Tunas Karya berdiri sejak tahun 1968. Sekolah ini di prakarsai oleh PTP IX dengan nama SMP PTP IX batang kuis, seiring dengan perkembangan zaman PTP IX tidak sanggup lagi mengelola sehingga diserahkan kepada yayasan yang di prakarsai oleh 5 orang putra Batang Kuis yang berprestasi. Kemudian pada tanggal 10 Desember 1988 SMP PTP IX berganti nama menjadi SMP Tunas Karya batang Kuis

\section{Hasil \\ Karakteristik Responden}

Sampel pada penelitian ini terdiri dari 2 kelompok yaitu 55 orang siswa yang diberikan penyuluhan kesehatan dengan 
menggunakan media power poin dan 55 orang siswa kelas IX yang diberikan penyuluhan kesehatan dengan media leafleat. Gambaran karakteristik responden yang meliputi umur, jenis kelamin, pendidikan, dan lama bekerja yang dapat dilihat pada tabel 4.2.1.

Tabel 1. Karakteristik Responden Berdasarkan Umur, Jenis Kelamin, SMP Tunas Karya Batang Kuis Tahun SMP Tunas Karya Batang Kuis

\begin{tabular}{|c|c|c|c|c|c|}
\hline \multirow{2}{*}{$\begin{array}{l}\mathbf{N} \\
\mathbf{0}\end{array}$} & \multirow{2}{*}{$\begin{array}{l}\text { Karak- } \\
\text { teristik }\end{array}$} & \multicolumn{3}{|c|}{$\begin{array}{l}\text { Kelompok } \\
\text { Power point }\end{array}$} & \multirow{2}{*}{ 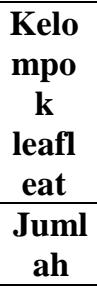 } \\
\hline & & \multicolumn{2}{|c|}{ Jumlah } & $\%$ & \\
\hline \multirow{4}{*}{1} & Umur & \multirow{3}{*}{\multicolumn{2}{|c|}{$\begin{array}{l}45 \\
10\end{array}$}} & & \\
\hline & 14 & & & 81,8 & 41 \\
\hline & tahun & & & 18,2 & 14 \\
\hline & Total & 55 & 100 & 55 & 100 \\
\hline \multirow{7}{*}{2} & Jenis & & & & \\
\hline & Kela & 10 & 18, & 22 & 40 \\
\hline & $\min$ & 45 & 2 & 33 & 60 \\
\hline & Laki- & & 81, & & \\
\hline & Laki & & 8 & & \\
\hline & $\begin{array}{l}\text { Perem } \\
\text { puan }\end{array}$ & & & & \\
\hline & Total & 55 & 100 & 55 & 100 \\
\hline
\end{tabular}

Pada penelitian ini, karakteristik responden yang dilihat meliputi umur, jenis kelamin, pendidikan, dan lama bekerja. Tabel 1 menunjukkan bahwa: Kelompok power point berdasarkan umur mayoritas responden berusia 14 tahun berjumlah 45 orang $(81,8 \%)$ dan pada kelompok leafleat mayoritas responden berusia 15 tahun berjumlah 41 orang $(74,5 \%)$

Kelompok power point berdasarkan jenis kelamin mayoritas responden berjenis kelamin perempuan berjumlah 45 orang $(81,8 \%)$ dan pada kelompok perlakuan dengan media leafleat mayoritas berjenis kelamin perempuan berjumlah 33 orang (60 $\%)$.
4.2. Pengaruh penggunaan power point dan leafleat Terhadap Pengetahuan siswa kelas IX Tentang Pertolongan pertama pada kecelakaan (P3K) di SMP Tunas Karya Batang Kuis Tahun 2017

Berdasarkan hasil penelitian pre test dari 55 orang siswa kelas IX yang berada di di SMP Tunas Karya Batang Kuis diketahui bahwa skor pengetahuan dapat dilihat pada tabel 4.2. Setelah dilakukan pre test, responden diberikan pendidikan kesehatan tentang P3K melalui power point dengan responden. Berikutnya dilakukan post test untuk melihat pengaruh penggunaan power point terhadap peningkatan pengetahuan siswa kelas IX pertolongan pertama pada kecelakaan. Selengkapnya hasil dapat dilihat pada tabel berikut:

\subsubsection{Perbedaan Pengetahuan siswa kelas IX Tentang pertolongan pertama pada kecelakaan (P3K) Pada Kelompok penggunaan power point di SMP Tunas Karya Batang Kuis Tahun 2017}

Tabel 2. Perbedaan Pengetahuan siswa kelas IX Tentang pertolongan pertama pada kecelakaan (P3K) Pada Kelompok penggunaan power point di SMP Tunas Karya Batang Kuis Tahun 2017

\begin{tabular}{lccc}
\hline Varibel & Mean & SD & n \\
\hline $\begin{array}{l}\text { Kelompok } \\
\text { Sebelum Perlakuan }\end{array}$ & 4,47 & 1,904 & 55 \\
& & & \\
Kelompok & 8,69 & & \\
$2,107 \quad 55$ & & & \\
Sesudah Perlakuan & & & \\
\hline
\end{tabular}

Berdasarkan tabel di atas, diketahui bahwa terdapat peningkatan nilai rata-rata pengetahuan siswa kelas IX pre test dan post test dengan power point yaitu dari 4,47 menjadi 8,69 sesudah diberi perlakuan dengan media power point.

Penggunaan Leafleat Terhadap Pengetahuan siswa kelas IX Tentang Pertolongan pertama pada kecelakaan (P3K) di SMP Tunas Karya Batang Kuis Tahun 2017 
Berdasarkan hasil penelitian pre test dari 55 orang siswa kelas IX yang berada di di SMP Tunas Karya Batang Kuis diketahui bahwa skor pengetahuan dapat dilihat pada tabel 4.2. Setelah dilakukan pre test, responden diberikan pendidikan kesehatan tentang Pertolongan pertama pada kecelakaan (P3K) melalui media leafleat dengan responden. Berikutnya dilakukan post test untuk melihat pengaruh media leafleat terhadap peningkatan pengetahuan siswa kelas IX tentang tentang Pertolongan pertama pada kecelakaan (P3K). Selengkapnya hasil dapat dilihat pada tabel berikut:

\subsubsection{Perbedaan Pengetahuan siswa kelas} IX Tentang pertolongan pertama pada kecelakaan (P3K) Pada Kelompok penggunaan Leafleat di SMP Tunas Karya Batang Kuis Tahun 2017

Tabel 3. Perbedaan Pengetahuan siswa kelas IX Tentang pertolongan pertama pada kecelakaan (P3K) Pada Kelompok penggunaan power point di SMP Tunas Karya Batang Kuis Tahun 2017

\begin{tabular}{|c|c|c|c|}
\hline Varibel & Mean & SD & $\mathbf{n}$ \\
\hline Kelompok & 4,13 & 1,611 & 55 \\
\hline \multicolumn{4}{|c|}{ Sebelum Perlakuan } \\
\hline $\begin{array}{l}\text { Kelompok } \\
\text { Sesudah Per }\end{array}$ & 10,15 & 1,660 & 55 \\
\hline
\end{tabular}

Berdasarkan tabel di atas, diketahui bahwa terdapat peningkatan nilai rata-rata pengetahuan siswa kelas IX pre test dan post test dengan media leafleat yaitu dari 4,13 menjadi 10,15 sesudah diberi perlakuan dengan media leafleat. .

\subsection{Perbedaan Rata-Rata Pengetahuan} Perawat Pre Test dan Post Test Dengan Media power point di SMP Tunas Karya Batang Kuis Tahun 2017

Tabel 4. Perbedaan Distribusi Rata-Rata Skor Pengetahuan siswa kelas IX Tentang Pertolongan pertama pada kecelakaan (P3K) Pre Test dan Post Test Dengan Media power point di di SMP Tunas Karya Batang Kuis Tahun 2017

\begin{tabular}{lccc}
\hline \multicolumn{1}{c}{ Variabel } & Mean & SE & $\begin{array}{c}\text { P } \\
\text { Value }\end{array}$ \\
\hline $\begin{array}{l}\text { Media power } \\
\text { point }\end{array}$ & 4,21 & 0,342 & 0,000 \\
Pengetahuan & & & \\
\hline Berdasarkan tabel diatas, diketahui bahwa
\end{tabular}

Berdasarkan tabel diatas, diketahui bahwa terdapat perbedaan nilai rata-rata point. Hasil uji pair-t test diperoleh nilai $\mathrm{p}=0,000$, artinya secara statistik menunjukkan terdapat perubahan pengetahuan pre test dan post test dengan penggunaan power point pada pengetahuan siswa kelas IX tentang Pertolongan Pertama Pada Kecelakaan

\subsection{Perbedaan Rata-Rata Pengetahuan} siswa kelas IX Pre Test dan Post Test Dengan penggunaan leafleat di SMP Tunas Karya Batang Kuis Tahun 2017

Tabel 5. Perbedaan Distribusi Rata-Rata Skor Pengetahuan siswa kelas IX Pre Test dan Post Test Dengan Media leafleat di SMP Tunas Karya Batang Kuis Tahun 2017

\begin{tabular}{cccc}
\hline \multicolumn{1}{c}{ Variabel } & Mean & SE & P value \\
\hline Media leafleat & & & \\
Pengetahuan & 6,01 & 0,272 & 0,000
\end{tabular}

Berdasarkan tabel di atas, diketahui bahwa terdapat perbedaan nilai rata-rata pengetahuan siswa kelas IX dengan media leafleat. Hasil uji pair-t test diperoleh nilai $\mathrm{p}=0,000$, artinya secara statistik menunjukkan terdapat perubahan pengetahuan pre test dan post test dengan penggunaan leafleat pada pengetahuan tentang Pertolongan Pertama Pada Kecelakaan

4.6 Perbedaan Rata-Rata Pengetahuan siswa kelas IX Post Test Dengan penggunaan power point dan leafleat di SMP Tunas Karya Batang Kuis Tahun 2017 
Tabel 6. Perbedaan Distribusi Rata-Rata Skor Pengetahuan siswa kelas IX Pre Test dan Post Test Dengan Media leafleat di SMP Tunas Karya Batang Kuis Tahun 2017

\begin{tabular}{lccc}
\hline \multicolumn{1}{c}{ Variabel } & Mean & SE & P value \\
\hline $\begin{array}{l}\text { Media power } \\
\text { point dan } \\
\text { leafleat }\end{array}$ & 1,455 & 0,362 & 0,04 \\
$\begin{array}{l}\text { Pengetahuan } \\
\text { Pen }\end{array}$ & & & \\
\hline
\end{tabular}

Berdasarkan tabel diatas, diketahui bahwa terdapat perbedaan nilai rata-rata pengetahuan siswa kelas IX dengan media power point dan penggunaan Leafleat. Hasil uji Independent sample test diperoleh nilai $\mathrm{p}=0,000$, artinya secara statistik menunjukkan terdapat perbedaan rerata skor pengetahuan siswa kelas IX yang bermakna antara kelompok dengan penggunaan power point dengan penggunaan leafleat. Skor pengetahuan dengan media leafleat lebih tinggi dibanding dengan media power point.

\section{PEMBAHASAN}

Pengaruh sesudah diberikan pendidikan kesehatan dengan Media Power point Terhadap Pengetahuan Siswa kelas IX Tentang Pertolongan pertama pada kecelakaan (P3K) di SMP Tunas Karya Batang Kuis Tahun 2017

Pemilihan Power point sebagai media penyuluhan kesehatan dapat diterima dengan baik oleh responden. Media ini menawarkan penyuluhaan yang lebih menarik dan tidak monoton. Penyuluhan dengan audiovisual menampilan gerak, gambar dan suara sedangkan penyuluhan dengan media cetak menampilkan tulisan dan suara penyuluh secara langsung yang membuat terkesan formal. Pada saat pelaksanaan penelitian, sebagian besar responden mempunyai keingintahuan yang besar sampai selesai dengan serius.

Berdasarkan analisis terlihat adanya peningkatan rata-rata nilai baik pada pengetahuan. Peningkatan tersebut lebih besar pada kelompok sesudah diberi perlakuan dari pada kelompok yang belum diberi perlakuan . Berdasarkan penelitian didapatkan nilai berdasarkan pengetahuan sesudah diberi media power point yaitu pengetahuan baik sebanyak 8 orang (14,5\%), pengetahuan cukup sebanyak 18 orang $(32,7 \%)$, dan kurang sebanyak 29 orang $(52,7 \%)$.

Berbagai faktor yang mungkin berpengaruh pada penyuluhan adalah penyuluh, materi yang diberikan, media penyuluhan serta sasaran yang disuluh. Materi yang disampaikan cukup menarik dilihat dari antusias responden, media pada metode ceramah pun menggunakan media power point dimana peneliti mencoba memaksimalkan semua panca indra dalam penelitian ini baik penglihatan maupun pendengaran.

Hasil beberapa penelitian menunjukkan bahwa mahasiswa kesiswa kelas IXan belum siap untuk melakukan Basic Life Support (BLS). Dalam penelitian Chandrasekaran (2010) sebanyak 98,4\% (314 orang) mahasiswa kesiswa kelas IXan memiliki kesadaran yang rendah terhadap BLS, dengan nilai dibawah 50. Berdasarkan penelitian yang dilakukan oleh Josipovic (2009) sebanyak 22\% mahasiswa kesiswa kelas IXan dan Chiropractic menyatakan tidak siap untuk melakukan CPR.

Pengetahuan bantuan hidup dasar dianggap merupakan keterampilan yang mendasar bagi siswa kelas IX (Parajulee \& Selvaraj, 2011). Keterampilan P3K menjadi penting karena didalamnya diajarkan tentang bagaimana teknik dasar penyelamatan korban dari berbagai kecelakaan atau musibah sehari-hari yang biasa dijumpai. Oleh karena itu, setiap tenaga kesehatan khususnya siswa kelas IX wajib menguasai dan siap untuk melakukan CPR dimanapun dan kapanpun (Keenan, Lamacraft \& joubert, 2009).

Pemberian penyuluhan tentang P3K dengan metode power point ternyata mampu meningkatkan pengetahuan siswa kelas IX. Hasil penelitian ini sesuai dengan penelitian yang telah dilakukan oleh Barr et al. (2010)

Penelitian lain yang mendukung adalah penelitian dari Resmi Pangaribuan (2017) "Pengaruh media pendidikan kesehatan tentang Bantuan Hidup Dasar (BHD) terhadap pengetahuan studi Eksperiment pada perawat pelaksana di Rumah Sakit Tk. II Putri Hijau Medan 
Penelitian memberikan intervensi berupa memperlihatkan audio Visual dan pantom pada responden. Hasil penelitian ada pengaruh yang bermakna antara intervensi audio visual dan pantom dengan tingkat pengetahuan $(\mathrm{p}=0,05)$ dan menunjukkan adanya peningkatan pengetahuan.

Hasil penelitian lain yang sesuai adalah pengaruh pendidikan kesehatan dengan metode video tentang cara mahasiswa kebidanan, bayi terhadap perubahan perilaku ibu primipara dalam menolong bayi baru lahir (Suryani, 2008). Penelitian ini dilakukan dengan pemutaran video sebanyak satu kali dan menggunakan design one group pre test post test. Hasil penelitian menunjukkan ada perubahan pengetahuan, sikap dan keterampilan ibu sebelum dan sesudah diberikan penyuluhan.

Media pembelajaran video/film disebut juga gambar hidup (motion pictures) yang meluncur secara cepatdan diproyeksikan secara sehingga menimbulkan kesan hidup dan bergerak. Alat bantu lihat pandang dengar adalah alat bantu pendidikan kesehatan yang lebih dikenal dengan nama "power point Aids" (AVA) yang dapat membantu menstimulasi indera penglihatan dan pendengaran pada waktu proses pembelajaran (Susilana dan Riyana, 2009). Pengetahuan adalah hasil tahu, dan ini terjadi setelah orang melakukan penginderaan terhadap suatu objek tertentu. Penginderaan terjadi melalui panca indera manusia, yaitu penglihatan, pendengaran, penciuman, rasa dan raba. Sebagian besar pengetahuan manusia diperoleh melalui mata dan telinga.

Salah satu strategi untuk memperoleh perubahan pengetahuan menurut WHO yang dikutip oleh Notoatmodjo (2014) adalah dengan pemberian informasi untuk meningkatkan pengetahuan sehingga menimbulkan kesadaran yang pada akhirnya orang itu akan memiliki sikap yang sesuai dengan pengetahuannya. Salah satu upaya pemberian informasi itu adalah dengan mdia power point. Pengetahuan adalah hasil penginderaan manusia, atau hasil tahu seseorang terhadap objek melalui indera yang dimilikinya (mata, hidung, telinga dan sebagainya). Pengetahuan seseorang terhadap suatu objek mempunyai intensitas atau tingkat yang berbeda-beda, yang dipengaruhi oleh intensitas perhatian dan persepsi terhadap objek tersebut. Sebagian besar pengetahuan manusia diperoleh melalui mata dan telinga

Pengetahuan adalah hasil dari tahu yang terjadi melalui proses sensoris khususnya mata dan telinga terhadap objek tertentu. Pengetahuan merupakan objek yang sangat penting untuk terbentuknya perilaku terbuka (overt behavior), perilaku tertutup (covert behavior) perilaku yang didasari pengetahuan umumnya bersifat langgeng (Riduwan, 2002).

Penyuluhan sebagai proses perubahan pengetahuan yang menuntut persiapan dan pengetahuan yang memadai bagi penyuluh maupun sasarannya. Siswa kelas IX pelaksana dapat mengubah pengetahuan melalui informasi yang telah didapat melalui penyuluhan dengan median power point tentang bantuan hidup dasar sehingga setelah dilakukan post test terjadi peningkatan pengetahuan pengetahuan siswa kelas IX tentang bantuan hidup dasar.

Peningkatan tersebut diartikan sebagai hasil dari penyuluhan kesehatan dengan media audiovisual dan dilanjutkan dengan diskusi yang diberikan. Pemilihan dan penggunaan media merupakan salah satu komponen yang penting. Menurut Maulana (2009), pancaindera yang banyak menyalurkan pengetahuan ke otak adalah mata (kurang lebih 75\% sampai 87\%), sedangkan $13 \%$ sampai $25 \%$, pengetahuan manusia diperoleh dan disalurkan melalui pancaindera yang lain. Media seharusnya mampu merangsang atau memasukan informasi melalui berbagi indera. Semakin banyak yang dirangsang maka masuknya informasi akan semakin mudah. Media audiovisual memberikan rangsangan melalui mata dan telinga. Perpaduan saluran informasi melalui mata yang mencapai $75 \%$ dan telinga $13 \%$ akan memberikan rangsangan yang cukup baik sehingga dapat memberikan hasil yang optimal.

Menurut asumsi peneliti bahwa pemilihan power point sebagai media penyuluhan kesehatan dapat diterima dengan baik oleh responden. Media ini menawarkan penyuluhaan yang lebih menarik dan tidak 
monoton. Penyuluhan dengan power point menampilan gerak, gambar sedangkan penyuluhan dengan media cetak menampilkan tulisan dan suara penyuluh secara langsung yang membuat terkesan formal. Pada saat pelaksanaan penelitian, karena media ini terbilang baru sebagian besar responden mempunyai keingintahuan yang besar. Peningkatan pengetahuan siswa kelas IX setelah diberikan perlakuan merupakan akibat dari pemberian pendidikan kesehatan dengan media power point. Dengan demikian media power point sebagai media pendidikan kesehatan efektif digunakan untuk memberikan peningkatan pengetahuan kepada siswa kelas IX dalam meningkatakan pengetahuan tentang Pertolongan pertama pada kecelakaan (P3K) menjadi lebih baik.

\section{Pengaruh sesudah diberi pendidikan kesehatan dengan Media Leafleat Terhadap Pengetahuan Siswa kelas IX Tentang Pertolongan pertama pada kecelakaan (P3K) di SMP Tunas Karya Batang Kuis Tahun 2017}

Setelah diberikan pendidikan
kesehatan, terjadi peningkatan nilai
pengetahuan dari nilai berdasarkan
pengetahuan sesudah diberi media leafleat
yaitu pengetahuan baik sebanyak 10 orang
$(18,2 \%)$, pengetahuan cukup sebanyak 36
orang $(65,5 \%)$, dan pengetahuan kurang
sebanyak 9 orang $(16,4 \%)$.

Hasil ini menunjukkan bahwa pendidikan kesehatan yang dilakukan mengenai bantuan hidup dasar dapat meningkatkan pengetahuan responden. Diharapkan dengan peningkatan pengetahuan mengenai bantuan hidup dasar maka terbentuknya perilaku dalam penanganan bantuan hidup dasar. Hal ini sesuai dengan tujuan pendidikan kesehatan yaitu terjadinya perubahan pengetahuan individu keluarga, kelompok dalam memberi bantuan hidap dasar pada pasien sehat serta berperan aktif dalam upaya mewujudkan derajat kesehatan yang optimal.

\section{KESIMPULAN DAN SARAN Kesimpulan}

Berdasarkan hasil penelitian yang dilakukan oleh peneliti, kesimpulan dari penelitian ini adalah sebagai berikut:

Pengetahuan siswa SMP kelas IX sesudah diberikan pendidikan kesehatan dengan power point dan leafleat mengalami peningkatan hal ini dipengaruhi oleh diberikan dapat mengingat kembali tentang materi yang diberikan yaitu pertolongan pertama pada kecelakaan (Firs Aid). Rentang usia siswa SMP kelas IX yang menjadi responden dalam penelitian ini adalah adalah usia 14-15 tahun, pada usia ini masih mudah untuk menerima informasi yang diterimanya baik melalui power point ataupun Leafleat. Dan pada usia ini kemampuan seorang siswa SMP kelas IX dalam berfikir kritis dalam melakukan pertolongan pertama pada kecelakaan, selama ini dengan banyaknya kasus-kasus dan pengalaman di peroleh responden.

\section{Saran}

1. Kepada Pimpinan Yayasan

Untuk meningkatkan pengetahuan siswa SMP kelas IX tentang pertolongan pertama pada kecelakaan dengan membentuk Palang Merah Remaja untuk memberikan pertolongan kegawatdaruratan pertolongan segera dan siap pakai pada situasi urgent

2. Penelitian Selanjutnya Untuk dapat lebih melanjutkan topik tentang peningkatan pengetahuan siswa SMP kelas IX tentang Pertolongan pertama pada kecelakaan dengan faktor atau metode yang berbeda.

\section{DAFTAR PUSTAKA}

Arsyad, A. (2015). Media Pembelajaran. PT Rajagrafindo Persada. Jakarta

American Heart Association. (2015). Fokus Utama Pembaruan Pedoman American Heart Association 2015 untuk CPR dan ECC.

Aminuddin. (2013). Analisis Faktor yang Berhubungan dengan Kesiapan Siswa kelas IX dalam Menangani Cardiac Arrest di Ruangan ICCU dan ICU RSU Anutrapura Palu. Skripsi. Poltekes Kemenkes. Palu. 
Azwar. S. (2010). Sikap Manusia teori dan pengukurannya; Yogyakarta, Pustaka Belajar

Chandrasekaran S, Kumar S, Bhat SA, Saravanakumar, Shabbir PM, ChandrasekaranVP. (2010). Awareness of Basic Life Support among Medical, Dental, Nursing Student and Doctors. Indian Journal of Anaesthesia.

Daryanto. (2010). Media pembelajaran perannya sangat penting bagi pembelajaran: Yogyakarta. Gava Media

Dahlan, S. (2014). Jurnal Kesiswa kelas IXan. Manado. Program Studi Ilmu Kesiswa kelas IXan Fakultas Kedokteran Universitas Sam Ratulangi.

Fitriani, S. (2011). Promosi Kesehatan Edisi Pertama.Yogyakarta : Graha Ilmu.

Garini, W. (2004). Pengaruh intervensi VCD metode siswa kelas IXan bayi terhadap pengetahuan ibu bayi berat badan lahir rendah di RSUD Ciawi Bogor Jawa Barat. Tanggal 10 Juni 2017.

Hasanah, U.N. (2015). Hubungan Tingkat Pengetahuan Dengan Keterampilan Siswa kelas IX Dalam Melakukan Tindakan Pertolongan pertama pada kecelakaan (First Aid) di RSUD Kabupaten Karanganyar. Skripsi. STIKes Kusuma Husada. Surakarta.

Khoiron, N, (2014). Efektifitas pendidikan kesehatan dengan menggunakan media leafleat dan media Slide power point terhadap perubahan pengetahuan, sikap dan perilaku deteksi dini kanker serviks, Jurnal Fakultas Ilmu Kesehatan Universitas Muhammadiyah Surakarta

Lontoh, C. (2013). Pengaruh Pelatihan Teori Bantuan Hidup Dasar Terhadap Pengetahuan Resusitasi Jantung Paru Siswa-Siswi SMA Negeri 1 Toili. Skripsi. Manado : Program Studi Ilmu Kesiswa kelas IXan Fakultas Kedokteran Universitas Sam Ratulangi Manado
Maulana, H. (2009). Promosi kesehatan. Jakarta: EGC

Musliha, (2010). Gawat Darurat. Nuha Medika. Yogyakarta

Mubarak, W. (2011). Promosi Kesehatan untuk Kebidanan. Jakarta:Salemba Medika.

Notoatmodjo, S. (2014). Ilmu Perilaku Kesehatan. Jakarta: Rineka Cipta.

Notoadmodjo, S. (2010). Metodologi penelitian adisi revisi. Jakarta Rineka cipta

Pangaribuan, R. (2017). Pengaruh pendidikan kesehatan terhadap pengetahuan bantuan hidup dasar, studi eksperimen pada perawat pelaksana di Rumah Sakit TK. II Putri Hijau Medan, Jurnal Kesehatan (Jumatik).

Pratiknya, B. (2011). Metodologi Penelitian Kedokteran dan Kesehatan Masyarakat. TIM, Jakarta

Sugiono, (2011). Metode Penelitian. Bandung; IKPL

Susilo, R. (2011). Pendidikan Kesehatan . Yogyakarta : Nuha Medika.

Wijaya, S.I. (2016). Tingkat pengetahuan bantuan Hidup dasar pada masyarakat di kecamatan Denpasar Utara. Seminar Nasional. Kesdam IX/ Udayana Denpasar: Bali

http://harian.analisadaily.com/kota/news/pen derita-jantung-koroner-terusmeningkat/232591/2016/04/25dibuka tanggal 30 Maret 2017 jam 10.00 wib 